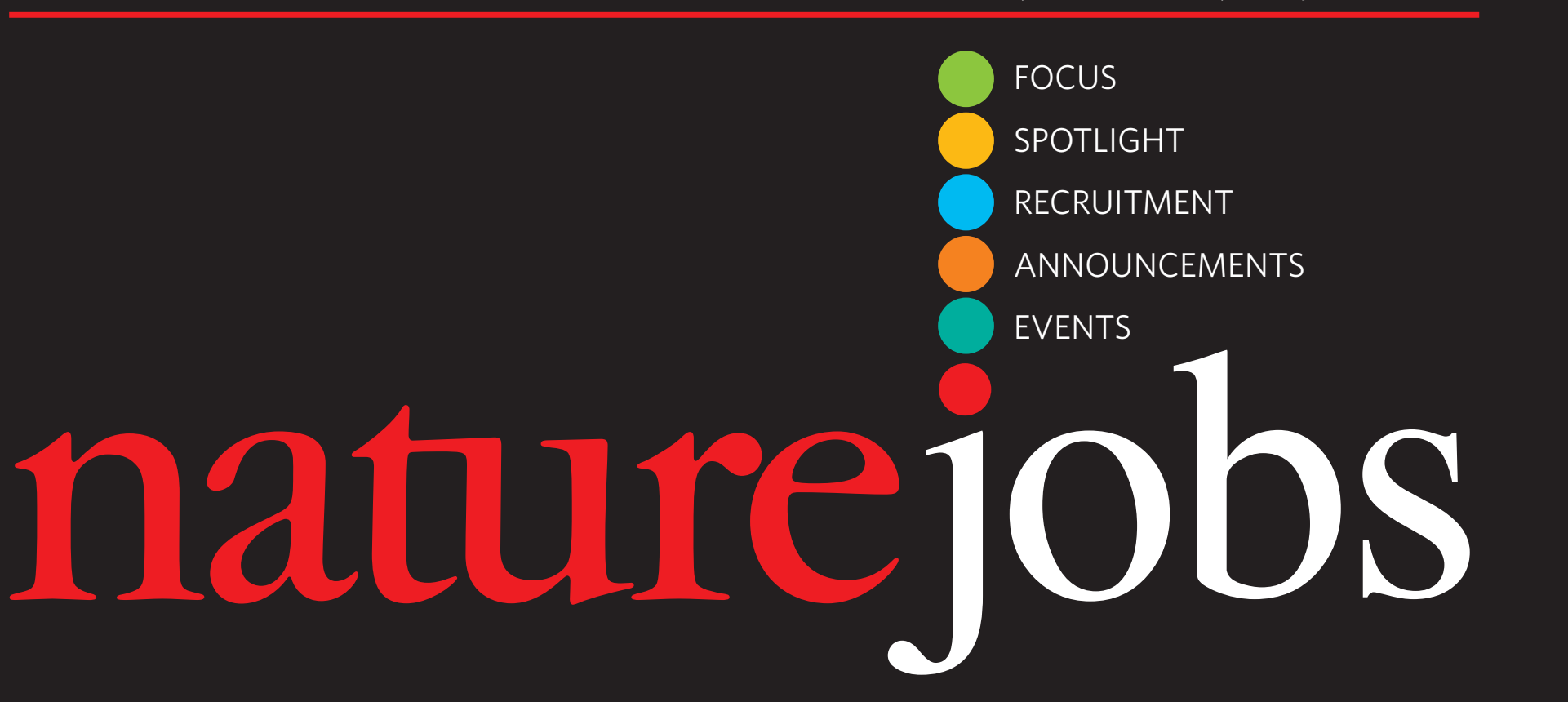

\title{
Stemming the tide
}

Arnold Schwarzenegger, movie star and governor of California, helped bring stem-cell funding to the state with the much-debated Proposition 71. But it is not clear whether the $\$ 3$-billion initiative will stop stem-cell scientists leaving the United States. A panel discussing the business and financing of stem-cell research last week at the University of California, San Francisco, was split about the initiative's ability to slow the stem-cell brain drain.

The panellists, convened by BayBIO, a regional biotechnology organization and co-sponsored by

Naturejobs, agreed that Proposition 71 was intended to keep the best stem-cell scientists in California. But they weren't sure how effective it would be.

Rik Derynck, a tissue biologist at the university, says that money from the initiative hasn't yet appeared in any research department coffers. Although the funding would be helpful, it's not vital for retaining scientists interested in stem-cell research. Much basic work doesn't rely on human embryonic stem cells, the kind restricted under US government funding rules. And private foundations and businesses will fund research they find relevant. Stacy

CONTACTS

Publisher: Ben Crowe

Editor: Paul Smaglik

Marketing Manager: David Bowen

European Head Office, London

The Macmillan Building, 4 Crinan Street London N1 9XW, UK

Tel: +44 (0) 2078434961

Fax: +44 (0) 2078434996

e-mail:naturejobs@nature.com

Naturejobs Sales Director:

Nevin Bayoumi (4978)

European Sales Manager:

Andy Douglas (4975)
Natureevents: Sille Opstrup (4994)

UK/RoW/Ireland/Italy:

Nils Moeller (4953)

Irene Viglia-Atton (4944)

Scandinavia/Spain/Portugal:

Evelina Rubio Håkansson (4973)

France/Switzerland/Belgium:

Amelie Pequignot (4974)

Germany/Austria/The Netherlands:

Reya Silao (4970)

Advertising Production Manager:

Billie Franklin

To send materials use London

address above.

Tel: +44 (0) 2078434814

Taylor, a lawyer at Foley \& Lardner's San Diego office, also points out that the United States is in an enviable position as regards intellectual property, at least for the early stages of applied research. Although the country is one of several with stem-cell policies that she calls "restrictive", it has the bulk of stem-cell patents at present.

But from a business perspective, this may not be enough. Antoun Nabhan, who works for a venture-capital firm in San Diego, predicts that countries with more lenient policies, such as Britain, Korea and Singapore, will gain an advantage.

Jobs in the stem-cell industry will follow the first success. Given the political climate, there is no guarantee that this success will come in the United States - even with more state-led initiatives like California's.

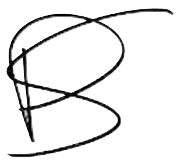

\section{Paul Smaglik, Naturejobs editor}

Fax: +44 (0) 2078434996 e-mail: naturejobs@nature.com

Naturejobs web development: Tom Hancock Naturejobs online production: Niamh Shields

European Satellite Office

Germany/Austria/

The Netherlands:

Patrick Phelan

Tel: +498954905711

Fax: +498954905720

e-mail:p.phelan@nature.com

US Head Office, New York

345 Park Avenue South,

10th Floor, New York,
NY 10010-1707

Tel: +18009897718

Fax: +18009897103

e-mail: naturejobs@natureny.com

US Sales Manager: Peter Bless

Japan Head Office, Tokyo

Chiyoda Building,

2-37 Ichigayatamachi,

Shinjuku-ku,

Tokyo $162-0843$

Tel: +81332678751

Fax: +81332678746

Asia-Pacific Sales Director: Rinoko Asami

e-mail: r.asami@naturejpn.com 